\title{
BALZAC LÊ STENDHAL, MACHADO LÊ EÇA DE QUEIRÓS
}

\section{MARTA DE SENNA}

Fundação Casa de Rui Barbosa

Rio de Janeiro, Rio de Janeiro, Brasil

Resumo: Em setembro de 1840, Balzac escreveu longo artigo para a Revue Parisienne sobre $A$ cartuxa de Parma, então recentemente publicada por Stendhal. Embora elogie as qualidades do livro, nos parágrafos finais é muito crítico da obra do colega, de um modo que nos leva a inferir que o que condena na Cartuxa é que não é o romance que ele, Balzac teria escrito. Em abril de 1878, Machado de Assis escreveu para O Cruzeiro dois artigos sobre $O$ primo Basílio (aludindo também ao primeiro romance de Eça, $O$ crime do padre Amaro). Este artigo argumenta que a crítica do brasileiro ao romance do português tem por fundamento as afinidades cruzadas entre Eça e Balzac e entre ele mesmo, Machado, e Stendhal.

Palavras-chave: Stendhal, Balzac, Eça de Queirós, Machado de Assis, romance, Realismo.

\section{BALZAC READS STENDHAL, MACHADO READS EÇA DE QUEIRÓS}

Abstract: In September 1840, Balzac wrote a long article for the Revue Parisienne about Stendhal's recently-published La Chartreuse de Parme. Though praising the book's qualities, Balzac is very critical of his fellow writer's work, in a way that leads us to infer that what he criticises in La Chartreuse de Parme is that it is not the novel he would have written himself. In April 1878, Machado de Assis wrote two articles for O Cruzeiro about Eça de Queirós's recently published $\mathrm{O}$ primo Basílio (also alluding to his first novel, $\mathrm{O}$ crime do padre Amaro). This paper claims that the Brazilian criticism of the Portuguese novel is based on the affinities between Eça and Balzac and between Machado and Stendhal.

Keywords: Stendhal, Balzac, Eça de Queirós, Machado de Assis, novel, Realism. 
$\mathrm{E}$ ste artigo $^{1}$ examina o interesse do jovem crítico Machado de Assis pela ficção de Eça de Queirós, que na década de 1870 fazia furor no Brasil. Seu foco principal recai sobre os dois escritores lusófonos, sendo as referências a Balzac e a Stendhal, autores de fortunas críticas longas e complexas, apenas operacionais para o argumento.

Em abril de 1878, Machado de Assis publicou dois artigos demolidores sobre $O$ primo Basílio, de Eça de Queirós, que saíra em livro em fevereiro daquele ano. ${ }^{2}$ Como várias outras pessoas, ${ }^{3}$ penso que o que Machado criticou foi, em resumo, aquilo que o romance tinha de... não machadiano.

Em setembro de 1840, Balzac havia publicado, na Revue Parisienne, um longo texto de crítica ao romance La Chartreuse de Parme, de Stendhal. Nas palavras de Marie-Ėve Théranty, "[o] júbilo do resumo [do enredo do romance] é seguido por um gesto de reescritura e recomposição do romance" (THÉRANTY, 2014, p. 27). ${ }^{4}$ De fato, parece que o que desagrada a Balzac na Chartreuse (e portanto ele "precisa" reescrever) é aquilo em que o livro nada tem de balzaquiano, sobretudo a sua "falta de método". 5

A partir da relação entre esses quatro escritores, gostaria de convidar o leitor a pensar num quiasmo. Não no sentido literário ou retórico de disposição cruzada da ordem das partes simétricas de duas frases, de modo que formem uma antítese ou um paralelo, mas no sentido leigo do termo: um cruzamento, uma disposição de elementos em cruz. Gostaria de sugerir que Eça de Queirós (o autor criticado por Machado de Assis) está para Balzac (o crítico de Stendhal), assim como Machado (o crítico de Eça) está para Stendhal (o autor criticado por Balzac).

Lembremos a reação de Julião, no capítulo 4 de $O$ primo Basílio, quando Sebastião lhe diz que Luísa e Basílio tinham tido um namoro quando ela era ainda uma menina, namoro depois rompido pelo primo, por carta:

\footnotetext{
${ }^{1}$ Este artigo tem origem numa apresentação na Universidade de Indiana, em 2015. Uma primeira versão, em inglês, foi publicada na Revista de Estudos Literários (SENNA, 2016).

${ }^{2}$ Os artigos foram publicados em $O$ Cruzeiro, nos dias 16 e 30 de abril.

${ }^{3}$ Entre tais pessoas, está o professor Jorge Fernandes da Silveira, que teria dito, em uma de suas aulas de literatura portuguesa nos anos 1970: "Machado criticou o livro que nunca escreveria" (GOMES, 2002, p. 504).

${ }^{4}$ No original: "à la jubilation du résumé succède le geste de réécriture et de recomposition de l'œuvre".

5 "[...] évidemment ce livre manque de méthode." (BALZAC, on-line). Resposta de Stendhal: "J'ai fait quelques plans de romans, je ne saurais en disconvenir, mais faire un plan me glace." (STENDHAL, on-line).
} 
- Tu sabes que ele foi namoro da Luísa? - disse Sebastião, baixo, como assustado da gravidade da confidência.

[...] Foi. [...] Estiveram para casar. Depois o pai faliu, ele foi para o Brasil, e de lá escreveu a romper o casamento.

Julião sorriu, e encostando a cabeça à parede:

- Mas isso é o enredo da Eugênia Grandet, Sebastião! Estás-me a contar o romance de Balzac! Isso é a Eugênia Grandet! (QUEIRÓS, 1966b, p. 953)

A admissão, por meio de uma de suas personagens, da possível semelhança do enredo do seu romance com a trama do de Balzac, é apenas uma das muitas referências ao autor francês feitas por Eça de Queirós, não somente em sua ficção, ${ }^{6}$ mas, principalmente, em sua correspondência. Seleciono uma carta, dirigida a Teófilo Braga, de março de 1878, logo após a publicação de $O$ primo Basílio, na qual diz: "Pobre de mim - nunca poderei dar a sublime nota da realidade eterna, como o divino Balzac [...]" (QUEIRÓS, 1966a, p. 517-518). E isto para não mencionar sua ideia de escrever uma espécie de "Comédie Humaine" portuguesa, "Cenas da Vida Portuguesa", que acabou por nunca produzir como tal, mas sobre a qual escreveu várias vezes a amigos, entre os quais o seu editor do Porto, Ernesto Chardron:

Eu tenho uma ideia, que penso daria excelente resultado. É uma coleção de pequenos romances, não excedendo de 180 a 200 páginas, que fosse a pintura da vida contemporânea em Portugal: Lisboa, Porto, províncias: políticos, negociantes, fidalgos, jogadores, advogados, médicos - todas as classes, todos os costumes entrariam nessa galeria.

A coisa poderia chamar-se "Cenas da Vida Portuguesa". (apud ROSA, 19[??], p. 106)

Stendhal, por outro lado, até onde pude ler, não é jamais mencionado na ficção de Eça de Queirós, figurando quase de passagem apenas na carta em francês ao editor de La Revue Universelle, a qual passou a ser o prefácio de $O$ mandarim (1884), a partir de sua quinta e póstuma edição. Aí, Eça menciona o autor de $O$ vermelho e o negro, declarando que não faria sucesso em Portugal. ${ }^{7}$

\footnotetext{
${ }^{6}$ Em Os Maias, há a "Vila Balzac" de João da Ega, que tem "um olho de Balzac". Em O conde de Abranhos há duas referências: ao próprio autor e ao père Grandet, com sua proverbial avareza.

${ }^{7}$ Agradeço ao professor Carlos Reis por essa informação, que me deu durante colóquio na Universidade de Indiana, em 2015.
} 
Contrariamente, no prólogo dirigido ao leitor de Memórias póstumas de Brás Cubas, o narrador de Machado afirma: "Que Stendhal confessasse haver escrito um de seus livros para cem leitores, cousa é que admira e consterna" (ASSIS, 1971, p. 513). Balzac é referido apenas duas vezes na ficção do autor, ${ }^{8}$ embora em sua biblioteca ele tivesse 17 volumes de "La Comédie Humaine", um volume de suas peças de teatro, um de seus contes drôlatiques e um de sua correspondência. Talvez seja relevante notar que, embora Stendhal fosse um escritor bem menos prolífico do que Balzac, Machado possuía 22 obras do autor. E embora aluda a Stendhal somente duas vezes mais, isto é, quatro vezes no total, ${ }^{9}$ o autor brasileiro revela conhecimento mais íntimo de sua produção, da qual se refere a dois livros distintos: De l'amour e La chartreuse de Parme. De Balzac, apenas o nome.

A diferença entre Machado e Balzac é muito bem sintetizada por Franco Moretti no seu $O$ burguês: entre a literatura e a história, num curto subcapítulo em que discute a relação que têm com o dinheiro uma das personagens de Balzac (Doguereau, de As ilusões perdidas) e Brás Cubas (MORETTI, 2014, p. 151-155), tópico a que pretendo voltar brevemente um pouco adiante.

Para além de detectar a afinidade entre Eça de Queirós e Balzac e entre Machado de Assis e Stendhal, quero argumentar que é com base nessa afinidade que se constrói a crítica a $O$ primo Basílio e, menos extensamente, a $O$ crime do padre Amaro.

O crítico faz objeções a "um autor, que não esquece nada, e não oculta nada [...]" e à nova estética (o Realismo-Naturalismo), para a qual só se alcançará a perfeição "no dia em que nos disser o número exato dos fios de que se compõe um lenço de cambraia ou um esfregão de cozinha" (ASSIS, 1973, p. 904). Para resumir, Machado acusa os dois primeiros romances de Eça por quatro razões principais: a primeira, a excessiva fidelidade do autor ao Realismo de Zola; a segunda, o fato de Luísa, a protagonista de $O$ primo Basílio, ser um títere e não uma pessoa moral; a terceira, certo prazer na descrição do que é imoral e repulsivo, o que seria uma concessão ao (mau) gosto do público; a quarta, a substituição do principal pelo acessório.

\footnotetext{
${ }^{8}$ Nos contos "Um homem superior" (1873) e "O empréstimo" (1882).

9 Três vezes em Memórias póstumas de Brás Cubas e uma no conto "Maria Cora" (primeira versão em $A$ Estação, 1898, com o título de "Relógio parado"; segunda versão em Relíquias de casa velha, 1906).
} 
Como sabe o leitor interessado na recepção do segundo romance de Eça de Queirós, nada aí é substancialmente diferente do que Ramalho Ortigão (possivelmente o amigo mais chegado de Eça) dissera em seu artigo impresso na Gazeta de Notícias, do Rio de Janeiro, duas semanas antes, imediatamente após a publicação do romance: pecava por certo mau gosto, pelo excesso de pormenores, pelo caráter explícito das "cenas de alcova", pela inconsistência das personagens (com exceção de Juliana) (ORTIGÃO, 1878, p. 1). Mais relevante para o meu argumento, porém, é a carta de Eça a Rodrigues de Freitas, também de 1878, agradecendo-lhe pelo artigo elogioso ao romance: "O que lhe agradeço é a sua defesa geral do 'Realismo'. Os meus romances importarão pouco; [...]; o que importa é o triunfo do Realismo" (QUEIRÓS, 1966a, p. 140-142). Ora, isto era precisamente o que Machado reprovava mais fortemente, como declararia no ano seguinte, em outra famosa peça crítica: "a realidade é boa, o realismo é que não presta para nada" (ASSIS, 1973, p. 830).

Muito se escreveu sobre a matéria, tendo os defensores de Eça no Brasil levado menos de uma semana para reagir ferozmente ao artigo de Machado. ${ }^{10}$ No fim dos anos 1990, uma imputação bem-humorada de parcialidade "de olho no mercado" foi sugerida por Marisa Lajolo. Ela argumenta que a condenação do romance de Eça por Machado foi uma espécie de estratégia para minar o prestígio de um livro sobre o adultério, que chegava ao Brasil quando ele próprio provavelmente já estaria ruminando um romance que também tratava de adultério (entre outros assuntos) - Memórias póstumas de Brás Cubas, publicado serializado em 1880 e em livro em 1881 (LAJOLO, 1997, p. 438-445). Sem endossar integralmente a suspeita de Lajolo com relação ao viés mercadológico da crítica de Machado - que, em termos intelectuais e artísticos, teria sido um ato de má-fé - vou aceitar a pista de que devemos lê-la no contexto da produção de sua própria ficção. Mas proponho que consideremos não Brás Cubas, e sim o romance precedente, Iaiá Garcia.

Poucas pessoas sabem que a primeira edição desse romance está salpicada de termos e expressões "naturalistas", como "instinto" ou "índole", todos banidos pelo autor na segunda edição (1899), que foi a definitiva, aquela em que todas as subsequentes se basearam. O melhor exemplo é, talvez, o do capítulo 13, quando Estela está em conflito entre o "amor comprimido" por Jorge e a "tranquilidade doméstica" que vivencia com Luís Garcia. Na primeira versão, a consonância

\footnotetext{
${ }^{10}$ Àqueles interessados na polêmica, recomendo o livro de José Leonardo do Nascimento (2008).
} 
com o Naturalismo: "não poderia nunca misturar esta água com aquele lodo" (ASSIS, 1975, p. 189); na segunda versão, o comentário é suprimido. Ao escrever Iaiá Garcia, estaria Machado seduzido pela nova escola, que ele chama - como o faz Eça na maioria das vezes - "Realismo"? Estaria ele sob o encanto da nova tendência? Ou, em vez disso, para adotar a abordagem desconfiada de Lajolo, quando, em 1877-1878, compunha Iaiá Garcia, estava Machado cioso da necessidade de fazer concessões ao gosto do público, algo que tão veementemente condenava em Eça?

José Luiz Passos, no seu Machado de Assis - o romance com pessoas, foi, até onde sei, o primeiro crítico a ressaltar a importância de Iaiá Garcia em relação à peça crítica de Machado sobre Eça de Queirós. Para além disso, Passos se detém na cena do capítulo 10, na qual Iaiá, então com 17 anos, flagra a reação de Estela quando seu marido lhe mostra uma carta a ele endereçada por Jorge alguns anos antes. Nela, Jorge relata a Luís Garcia o seu "eterno" amor por uma jovem cujo nome não revela, mas que, o leitor sabe, era Estela. Só de olhar a reação da madrasta, Iaiá imediatamente se dá conta de que ela amara Jorge no passado, e como que adivinha que ainda o ama no presente. De sua perspectiva, isso constitui uma ameaça à felicidade de seu amado pai. Nada é dito. Estela nem sequer nota que Iaiá adivinhou o seu segredo. Eis como o narrador resume a cena:

Iaiá adivinhou o passado de Estela; mas adivinhou demais. Galgou a realidade até cair no possível. Supôs um vínculo anterior ao casamento, roto contra a vontade de ambos, talvez persistente, mau grado aos tempos e às cousas. Tudo isso viu uma simples inocência de dezessete anos. Seu pensamento cristalino e virginal, nunca embaciado pela experiência, ignorava até as primeiras cismas de donzela. Não tinha ideia do mal; não conhecia as vicissitudes do coração. Jardim fechado, como a esposa do Cântico, viu subitamente rasgar-se-lhe uma porta, e esses dez minutos foram a sua puberdade moral. A criança acabara: principiava a mulher. (ASSIS, 1971, p. 453) ${ }^{11}$

\footnotetext{
${ }^{11}$ Há, n’A cartuxa de Parma, uma situação análoga, em que um único olhar decifra algo até então insuspeitado. Balzac comenta a passagem em sua crítica ao romance de Stendhal: "A duquesa está tão feliz que nem sonha com o conde. Esse efeito profundo, causado em Mosca por um único olhar, é irremediável." (BALZAC, on-line, tradução e grifo meu). Eis a passagem no romance, capítulo VII, Livro Primeiro: "Tudo ia às mil maravilhas até esse momento; mas, quando o ministro, muito satisfeito com Fabrício e até então unicamente atento aos seus feitos e gestos, olhou para a duquesa, achou-lhe olhos singulares. 'Este rapaz
} 
O que proponho é que, ao mesmo tempo em que Iaiá atinge a sua "puberdade moral", Machado, por sua vez, alcança sua própria maturidade estética. Ou seja: assim como Iaiá modificará seu comportamento e a maneira de encarar a vida, assim também Machado mudará sua concepção de construção de enredo e personagens. A partir daí, procede em sua ficção à criação de pessoas morais, personagens que enfrentam dilemas éticos, personagens semelhantes a Iaiá Garcia. ${ }^{12} \mathrm{O}$ que a Machado urge fazer, na ocasião em que escreve a sua crítica, é, de fato, criar personagens complexas, psicologicamente sofisticadas.

É claro que há uma enorme distância, em mais de um aspecto, entre os livros escritos por Eça em épocas e circunstâncias diferentes, a saber: entre o início de sua carreira de romancista e a partir da publicação de Os Maias. Mas, naquele momento, 1878, o que apresentavam ao crítico os romances de Eça de Queirós? Personagens completamente dominadas pelo ambiente social em que transitam, literatura produzida como caricatura dos valores burgueses, como instrumento de uma revolução estética, como parte de um programa de moralização social. Nas palavras de Carlos Reis,

Os primeiros romances queirosianos - O Crime do Padre Amaro e O Primo Basílio - são caracteristicamente obras de tese. Nelas, para além disso, circulam tipos que reclamam uma representatividade social e cultural ajustada ao propósito crítico que inspirava ambos os romances. [...] representam [essas personagens] comportamentos e mentalidades típicas que fazem de ambos os romances repositórios muito sugestivos de cenários humanos que deveriam ser corrigidos. (REIS, 2005, p. 87)

Desde os seus dias de estudante em Coimbra, Eça fora atraído por Proudhon (lembro a curiosa definição, dada por Eduardo Lourenço (1997, p. 707), do jovem Eça como o "filho de Proudhon e do rei Artur"), fascinado pelo organismo social de Spencer, pelo determinismo de Taine. Era, na altura, totalmente devotado à causa de uma literatura "utilitária" e queria escrever

causa aqui uma estranha impressão', disse consigo mesmo. Essa reflexão foi amarga: o conde já alcançara os cinquenta, palavra bem cruel e da qual talvez só um homem perfeitamente apaixonado pode sentir toda a repercussão" (STENDHAL, 1943, p. 170).

${ }^{12}$ Iaiá Garcia "é [...] a primeira protagonista do romance brasileiro a mudar drasticamente, a evoluir moral e psicologicamente entre a abertura e a conclusão da obra." (PASSOS, 2007, p. 93). 
romances com os quais acordaria os leitores portugueses de uma espécie de letargia moral, educacional e cultural. Como admite na mesma carta a Teófilo Braga já aqui citada, "[u]ma sociedade [a lisboeta] sobre estas falsas bases, não está na verdade: atacá-las é um dever. E neste ponto O Primo Basílio não está inteiramente fora da arte revolucionária, creio" (QUEIRÓS, 1966a, p. 517). Em suma: em 1876 (primeira versão de $O$ crime do padre Amaro, a que Machado de Assis leu) e em 1878 (O primo Basílio), ${ }^{13}$ Eça de Queirós, como muitos escritores de sua geração, estava a serviço de uma lógica de subordinação de suas personagens ao meio circundante. Isabel Pires de Lima fala, concisamente, de um "programa de moralização social" (LIMA, 1997, p. 716), que Eça perseguia à época.

Podem-se aplicar a Eça e seus companheiros da geração coimbrã as palavras de Paul Bourget sobre os romancistas franceses diretamente submetidos à influência de Flaubert, que, "aplicando-se sobretudo à transcrição do meio, foram suprimindo gradualmente de seus livros o estudo da vontade" (BOURGET, 1885, p. 166). ${ }^{14}$

Diz-se repetidamente que Schopenhauer exerceu forte influência sobre Machado. Sua visão do mundo como absurdo, sem sentido, assim como o seu pessimismo sombrio, se assemelha à inclinação machadiana ao desencanto e ao ceticismo moral. Mas eu gostaria de sustentar que, mais importante do que isso, o que Machado parece estar em vias de descobrir, nos dois últimos anos da década de 1870, é que o traço crucial, inalienável que caracteriza a cada um de nós, seres humanos, é a predominância da vontade sobre o intelecto. Mesmo que, em abril de 1878, Machado possivelmente ainda não houvesse lido Schopenhauer, conhecia decerto "o princípio de Helvétius" (lembremo-nos do título do capítulo 113 de Memórias póstumas): o amor de si mesmo é a única base da moral. Era, pelo fim da sexta década do século XVIII, uma nova teoria da moral, o interesse sendo o fundamento da justiça, e o prazer, a verdadeira interpretação do interesse (MORLEY, 1880, p. 322). Mesmo o autossacrifício

\footnotetext{
13 Alfredo Machado da Rosa (19[??]) compara as três versões (1876, 1878 e 1880), indicando como o conselho de Machado foi seguido por Eça.

${ }^{14}$ A primeira edição foi publicada em 1883. No original: "s'applicant surtout à la transcription des milieux, ils ont supprimé de plus en plus de leurs livres l'étude de la volonté". É curioso, embora irrelevante para o meu argumento, que Bourget identifique essa prevalência do contexto social em Flaubert, e não em Zola, por exemplo.
} 
resulta do fato de que a sensação que desperta se sobrepõe ao sofrimento correspondente e, portanto, é sempre consequência de cálculo.

Com efeito, o que o nosso romancista parece estar-nos dizendo com seu livro de 1880-1881 é que o interesse, fundado no amor ao prazer e na fuga do sofrimento, é a única fonte do juízo, da ação, e até da afeição de cada indivíduo um conceito não muito distante do "Wille" schopenhaueriano. Se não com as implicações metafísicas expressas pelo filósofo em sua obra máxima, Machado parece estar, no fim da década de 1870, começando a se dar conta de que o indivíduo é de fato uma manifestação da "Vontade". R. J. Hollingdale assinala que uma das razões para o sucesso de Schopenhauer é a sua tese de que a vontade é primária, ao passo que o intelecto é secundário. ${ }^{15} \mathrm{O}$ intelecto é mero instrumento da vontade, que determina todas as ações humanas.

Dificilmente se poderia pensar em algo mais machadiano do que essa prevalência. O exemplo de Moretti que usei acima o atesta: de um lado, a decisão racional de Doguereau de pagar menos pelo romance que Lucien de Rubempré lhe entregara (o qual, aliás, ele achara excelente); de outro, a decisão voluntarista de Brás Cubas de dar ao almocreve menos do que pensara de início, quando o pobre-diabo lhe salvara a vida. O uso que Moretti faz das duas cenas serve a um propósito diferente, uma vez que ele discute a mentalidade capitalista na França de Balzac, por oposição ao Brasil ainda semifeudal de Machado de Assis. Doguereau é um burguês por dentro e por fora. Brás se concebe como um aristocrata liberal. Doguereau é um comerciante, sua atitude é puramente mercantil, leva em conta oferta e demanda, preço, risco, lucro, prejuízo. A atitude de Brás emana de sua vontade, a vontade de um homem ocioso e volúvel, cuja vida é regida por um egoísmo estéril. Podem-se facilmente achar mais exemplos na ficção de Machado, como a vontade de grandeza do ensandecido Rubião, de Quincas Borba, vítima por sua vez da vontade voraz do inescrupuloso Palha e de sua mulher, Sofia. Pode-se também pensar na vontade do obstinado Bento Santiago, de Dom Casmurro, determinado a provar um adultério que a razão do leitor sugere jamais ter existido, a não ser na imaginação do narrador.

Em ensaio de 1969 e ainda muito pertinente, Gérard Genette (1969, p. 176) afirma que Stendhal era um discípulo de Helvétius. De fato, quando ainda muito

15 Ver a introdução, assinada por Hollingdale, de Essays and aphorisms de Schopenhauer (HOLLINGDALE, 1970, p. 35). 
jovem, quando ainda sequer era "Stendhal", mas simplesmente Henry Beyle, deixou-se impressionar pelos chamados "idéologues", entre os quais figurava Helvétius. Numa carta à irmã Pauline, datada de 8 de fevereiro de 1803, sustenta que o interesse pessoal é o motivo essencial de todas as ações humanas (LITTO, 1962, p. 42). Se De l'esprit, de Helvétius, não se encontra no que restou da biblioteca de Machado, encontram-se aí dois volumes da correspondência de Stendhal, ${ }^{16}$ cujo primo e testamenteiro, Romain Colomb, publicou em 1855. O primeiro volume contém uma espécie de prefácio, escrito por Merimée, intitulado "Notes et Souvenirs". Na terceira página, Merimée declara sobre Stendhal: "Frequentemente citava Helvétius com grande admiração, e até me fez ler o livro De l'esprit" (STENDHAL, 1855, p. vii). ${ }^{17}$

É possível especular que o interesse de Machado por Helvétius tenha sido despertado por Stendhal, cujos heróis mais importantes são helvetianos à sua maneira. Pensemos no atormentado Julien Sorel, cuja alma, segundo Georges Blin, "era carregada de vontade até a goela" (BLIN, 1983, p. 163) ${ }^{18}$ Lembremos a ambígua duquesa Sanseverina, movendo céus e terra para libertar o sobrinho amado, muito mais por razões egoístas e pelo amor inconfessável que tem por ele do que por razões verdadeiramente altruístas. Consideremos Fabrício voltando voluntariamente à Torre Farnese, para desespero da tia, submetendose à mais penosa das existências, pela vontade de ficar próximo de Clélia Conti.

Os heróis de Stendhal são imprevisíveis e indefiníveis, dotados de múltiplos sentimentos contraditórios. E são invariavelmente movidos pela paixão (ou vontade, ou interesse), aqui entendida como resultado de forças confusas e conflitantes que os empurram para ações que na maioria das vezes acarretam imenso sofrimento. Nas palavras de Leyla Perrone-Moisés, "[a personagem de Stendhal] é uma entidade em vias de se constituir na própria narrativa" (PERRONE-MOISÉS, 2006, p. 24). Quanto à sua relação com a exatidão, tão cara a Balzac e aos realistas-naturalistas, Georges Blin (1983, p. 39) diz que sua falta de cuidado ia ao ponto de condenar Julien Sorel em virtude de certo artigo 1432 do código penal, que, na verdade, tinha menos de 500 artigos. $^{19}$

\footnotetext{
${ }^{16}$ Ambos os volumes foram publicados em 1855 (MASSA, 2001, p. 86).

${ }^{17}$ No original: "Il citait souvent Helvétius avec grande admiration, et même il m'obligea de lire le livre de l'Esprit."

${ }^{18}$ No original: "était chargée de volonté jusqu'à la gueule".

19 "[... il condamne Julien Sorel en vertu de certain article 1432 du code pénal", qui "n'en comptait pas cinq cent."
} 
Tinha uma espécie de fobia do inventário, da catalogação e das descrições materiais exaustivas (BLIN, 1983, p. 36). ${ }^{20}$

Ouçamos outra vez Gérard Genette:

O que é próprio do discurso stendhaliano não é a clareza; menos ainda a obscuridade (de que tinha horror, como truque para disfarçar a tolice e cúmplice da hipocrisia). Mas algo como uma transparência enigmática, que sempre, aqui e ali, desconcerta qualquer recurso ou hábito do espírito. (GENETTE, 1969, p. 192) ${ }^{21}$

Parece que pisamos em solo machadiano.

Por contraste, permito-me tomar emprestada a Alfredo Bosi (2018) passagem de um texto seu, recém-publicado. Estudando a relação entre Machado e seu primeiro grande crítico, Augusto Meyer, Bosi se alonga numa digressão que me vem a calhar aqui e que, por isso, transcrevo na íntegra, apesar de longa:

Não me furto ao prazer de evocar a comparação que o ensaísta [Meyer] faz entre Machado e Balzac. É pura figuração narrativa, dentro da qual as notações críticas estão apenas sugeridas, entremostradas, e, no entanto, dizem em lance imediato o que o discurso analítico teria que explicar longa, pesadamente. $\mathrm{O}$ que fazia Balzac em meio a suas dívidas e noites insones? Imaginava ou talvez recordasse uma casa velha ou uma cara desconhecida. Essa evocação era suficiente para que aquele "homem que se considerava prático, preocupado com cifras e especulações", varasse a noite a café e sonho para descrever a Maison du chat qui pelote, a rua dessa casa, o quarteirão dessa rua, mais o mundo do visível no invisível. Acabou-se a obsessão da dívida a pagar. A casa ideal assente nuns alicerces vagos, intuição da poesia que há nas velhas ruas onde ele andou, a conta do concierge, uma vontade de fazer concorrência ao registro civil. Mas, e o resultado? A casa ideal existe, as personagens estão de pé, o timbre das vozes imaginadas abafa os rumores da realidade. O gordo bateu asas para outra dimensão.

20 "L'inventaire, le catalogue et les exhaustives 'descriptions matérielles', dont Stendhal avait la phobie [...]."

${ }^{21}$ No original: "Le propre du discours stendhalien n'est pas la clarté; moins encore l'obscurité (qu'il avait en horreur, comme cache-sottise et complice de l'hypocrisie). Mais quelque chose comme une transparence énigmatique, qui toujours, ici où là, déconcerte quelque ressource ou habitude de l'esprit." 
Não é preciso alongar a citação, pois vale o que está implícito: Machado não seria jamais tomado pela febre da descrição plástica e vívida dos ambientes em que se movem as suas personagens. Basta-lhe um breve aceno, apenas o bastante para dar uma ideia da classe social ou do habitat dos homens e mulheres que irá submeter ao escalpelo de sua análise de moraliste. Nesta e só nesta é que vai exercer o seu dom de observador dos atos, palavras e silêncios da mascarada social. Fica a pergunta: como o leitor Augusto Meyer, encantado pelo ethos generoso da "Comédia Humana", voltou-se com tanta fidelidade, ano após ano, para o romance de um autor em tudo oposto às demasias de um demiurgo chamado Balzac? (BOSI, 2018, p. 200). ${ }^{22}$

Voltando agora ao meu contraste entre Balzac e Stendhal. As personagens stendhalianas são imprevisíveis, indefiníveis, dotadas de sentimentos diversos e contraditórios. As de Balzac, por outro lado, são mais consistentes, menos paradoxais, comportando-se de maneira mais facilmente previsível pelo leitor. Para ele, o leitor vai-se dando conta, uma personagem se tornará mais importante e significativa na medida em que representar um grupo social e quanto mais for uma espécie de encarnação de um conflito entre interesses opostos, quão mais diretamente for condicionada pela classe a que pertence. Para ele, é como se homens e mulheres existissem somente em sua inserção social. Como ressaltou um velho historiador marxista da cultura, "La comédie humaine não deve sua unidade interna às suas cadeias de ação, [...] mas ao predomínio da causalidade social e ao fato de que é, efetivamente, [...] a história da sociedade francesa moderna" (HAUSER, 1969, p. 60). ${ }^{23}$ Aqui, o solo parece queirosiano.

É importante assinalar que a ficção de Eça jamais retornará a um "naturalismo" tão escancarado como o que se revela (fico tentada a dizer que se professa) em seus dois primeiros romances, mesmo porque, à medida que Eça progredia como ficcionista, a fé nas qualidades estéticas e ideológicas do romance naturalista já dava sinais de colapso (REIS, 2005, p. 89).

De qualquer modo, não lamentemos a dureza do julgamento machadiano sobre um colega escritor. Não nos deixemos enganar pela reação polida e

22 A citação de Meyer é tirada de Machado de Assis (1935-1958) (MEYER, 2008, p. 115).

${ }^{23}$ Marie-ĖveThéranty vai ao encontro disso, na introdução mencionada na nota 4: "[...] Balzac se donnera pour tâche d'explorer les espèces sociales, comme Buffon [...] l'avait fait des espèces animales. [...] Balzac faisant concurrence à la science sociale naissante." (THÉRANTY, 2014, p. 30). 
igualmente cortante de Eça - como fora polida e cortante a reação de Stendhal a Balzac (STENDHAL, on-line). Não nos deixemos enganar pelos vários testemunhos de admiração mútua entre os dois autores nos anos finais do século XIX - por verdadeiro que fosse o elogio de Machado aos contos "José Matias" e "Perfeição" ou a $A$ ilustre casa de Ramires $;{ }^{24}$ por real que pudesse ter sido a admiração de Eça pelas Memórias póstumas. ${ }^{25} \mathrm{Em}$ vez disso, regozijemo-nos com a prosa, o estilo, a riqueza desses dois romancistas que, sendo em tantos aspectos tão diferentes entre si, são, até hoje - como o são Balzac e Stendhal na literatura francesa -, dois romancistas referenciais da literatura em língua portuguesa.

É tempo de concluir e para isso, permito-me uma digressão. Em artigo precioso, quase perdido em obscura revista literária do Rio de Janeiro (CORREIA, 1971) e recentemente publicado nesta Machado de Assis em linha, a professora Marlene de Castro Correia (2015) afirma que o exercício da crítica é difícil para Machado de Assis não por razões pessoais (sua notória timidez, ou sua aversão à controvérsia); nem por razões contextuais (a pobreza da produção literária brasileira em sua época) - como vem sendo proposto por analistas de diferentes gerações. É difícil, sustenta ela, porque é praticamente impossível conciliar a urbanidade que ele se impunha como crítico (tal como havia declarado em "O ideal do crítico", 1865) e a ironia e o humor que se tornariam a marca de sua maneira estética. Porém, a escassez das peças machadianas do tipo que a professora Castro Correia chama de "crítica pura" é compensada pela crítica literária que Machado faz dentro de sua ficção (CORREIA, 2015). A crítica "impura" (nos termos de Castro Correia, a que ele realiza não em artigos, mas em seus contos e romances) fustiga acima de tudo o lugar-comum, a prosa bombástica, amaneirada, pedante. Eça de Queirós igualmente os abomina. Se nos detivermos em $O$ primo Basílio e considerarmos a peça de Ernestinho Ledesma, Honra e paixão, dar-nos-emos conta de que, além de sua função estrutural no romance (como apontaram Silviano Santiago [1978] e Carlos Reis [2005]), ela serve ao autor no propósito de expor ao ridículo a literatura vã,

${ }^{24}$ Cartas a Magalhães de Azeredo sobre a Revista Moderna, que o amigo lhe mandara de Paris: "Os dois contos de Eça de Queirós, "Perfeição" e "José Matias", são lindos." [21 de julho de 1897]. "Começamos aqui a ler a Ilustre Casa de Ramires [...] A arte com que está posta, desenhada e pintada a principal figura é realmente admirável, e não é preciso falar particularmente da língua e do estilo, que fazem parte dele." [7 de dezembro de 1897] (LYRA, 1965, p. 199 e 200).

${ }^{25}$ Das quais, supostamente sabia de cor as páginas do capítulo 7, "O delírio" (MOOG, 1966, p. 287). 
vazia, desprovida de sentido, "sub-romântica", que se produzia em Portugal (e no Brasil) na época. Machado poderia muito bem subscrever a estratégia talvez menos enfaticamente, com menos adjetivos, com menor intensidade. Se nos lembrarmos dos seus "oradores de sobremesa", personagens que fazem discursos fastidiosos, intermináveis, ao fim de refeições de cerimônia; ${ }^{26}$ se considerarmos seus versejadores pomposos e vazios; ${ }^{27}$ se recordarmos a ironia implacável empregada na descrição de José Dias, de Dom Casmurro, enlevado com as próprias pérolas retóricas - facilmente poderemos verificar que Eça e Machado têm muito em comum.

Entretanto, se Castro Correia está certa (como acredito estar) ao sustentar que, embora tenha escrito poucos artigos de "crítica pura", Machado continuou a escrever crítica pela ficção afora, eu gostaria de sugerir que Dom Casmurro (1899) - na sua imprecisão de contornos quase impressionista, nos seus meiostons crepusculares, na sua ambiguidade para sempre irredutível a uma verdade única, no seu caráter deliberadamente lacunar - é a mais fina e sutil peça machadiana de crítica a $O$ primo Basílio.

\section{Referências}

ASSIS, Machado de. A nova geração. In: Obra completa. v. 3. Rio de Janeiro: José Aguilar, 1973. p. 809-836.

. Iaiá Garcia. Rio de Janeiro: Civilização Brasileira; Brasília: INL (Comissão Machado de Assis), 1975.

Iaiá Garcia. In: Obra completa. v. 1. Rio de Janeiro: José Aguilar, 1973. p. 391-509.

Memórias póstumas de Brás Cubas. In: Obra completa. v. 1. Rio de Janeiro: José Aguilar, 1973. p. 511-639.

O primo Basílio. In. Obra completa. v. 3. Rio de Janeiro: José Aguilar, 1966. p. 903-913.

BALZAC, Honoré de. Sur la Chartreuse de Parme [Revue Parisienne, 25 septembre 1840. Disponível em: <http://www.oeuvresouvertes.net/spip.php?article101>. Acesso em: 12 mar. 2015.

BLIN, Georges. Stendhal et les problèmes du roman. Paris: Librairie José Corti, 1983.

${ }^{26}$ Como os dos contos "Valério", "Adão e Eva" e como o Vilaça de Memórias póstumas de Brás Cubas.

${ }^{27}$ Como Luís Tinoco, de "Aurora sem dia". 
BOSI, Alfredo. Augusto Meyer: crítica machadiana e memória. Estudos Avançados. São Paulo, v. 32, n. 92, p. 195-208, abr. 2018. Disponível em: <http://www.scielo.br/ scielo.php?script=sci_Arttext\&pid=S0103-40142018000100195\&lng=pt\&nrm=iso $>$. Acesso em: 21 jun. 2018. http://dx.doi.org/10.5935/0103-4014.20180013. BOURGET, Paul. Essais de philosophie contemporaine. 3. ed. Paris: Alphonse Lemerre, 1885.

CORREIA, Marlene de Castro. Atualidade da crítica de Machado de Assis. Littera, Rio de Janeiro, n. 2, p. 3-21, maio/ago. 1971.

Atualidade da crítica de Machado de Assis. Machado de Assis em Linha: Revista Eletrônica de Estudos Machadianos, São Paulo, v. 8, n. 16, p. 3-26, dez. 2015. Disponível em: <http://www.scielo.br/scielo.php?script=sci_arttext\&pid=S1983-68212015000200 003\&lng=en\&nrm=iso>. Acesso em: 21 jun. 2018. http://dx.doi.org/10.1590/1983682120158161.

GENETTE, Gérard. Figures II. Paris: Seuil, 1969.

GOMES, Renato Cordeiro. Quando O primo Basílio chegou por aqui. In: CANIATO, Benilde J.; MINÉ, Elza (Orgs.). Abrindo caminhos: homenagem a Maria Aparecida Santilli. São Paulo: Pós-Graduação de Estudos Comparados de Literaturas de Língua Portuguesa da USP, 2002. p. 498-504.

HAUSER, Arnold. Historia social de la literatura y el arte. Madrid: Guadarrama, 1969. v. 3.

HOLLINGDALE, R. J. Introduction. In: SCHOPENHAUER, Arthur. Essays and aphorisms. London: Penguin Books, 1970.

LAJOLO, Marisa. Eça de Queirós e suas leitoras malcomportadas. In: MINÉ, Elza; CANIATO, Benilde J. (Orgs.). 150 anos com Eça de Queirós. São Paulo: Centro de Estudos Portugueses da FFLCH-USP, 1997. p. 438-445.

LIMA, Isabel Pires de. Fulgurações e ofuscações de Eros - O primo Basílio. In: MINÉ, Elza; CANIATO, Benilde J. (Orgs.). 150 anos com Eça de Queirós. São Paulo: Centro de Estudos Portugueses da FFLCH-USP, 1997. p. 715-722.

LITTO, Victor del. La vie intellectuelle de Stendhal: génèse et évolution de ses idées. Paris: Presses Universitaires de France, 1962.

LOURENÇO, Eduardo. O tempo de Eça e Eça e o tempo. In: MINÉ, Elza; CANIATO, Benilde J. (Orgs.). 150 anos com Eça de Queirós. São Paulo: Centro de Estudos Portugueses da FFLCH-USP, 1997. p. 707-714.

LYRA, Heitor, O Brasil na vida de Eça de Queirós. Lisboa: Livros do Brasil, 1965. MASSA, Jean-Michel. A biblioteca de Machado de Assis. In: JOBIM, José Luís (Org.). A biblioteca de Machado de Assis. Rio de Janeiro: Academia Brasileira de Letras; Topbooks, 2001.

MEYER, Augusto. Machado de Assis (1935-1958). 4. ed. Rio de Janeiro: José Olympio, 2008. 
MOOG, Vianna. Eça de Queirós e o século XIX. 5. ed. Rio de Janeiro: Civilização Brasileira, 1966.

MORETTI, Franco. O burguês: entre a literatura e a história. São Paulo: Três Estrelas, 2014.

MORLEY, John. Diderot and the encyclopaedists. London: Chapman and Hall, 1880.

NASCIMENTO, José Leonardo do. O primo Basílio na imprensa brasileira do século $X I X$. São Paulo: Editora da Unesp, 2008.

ORTIGÃO, Ramalho. Cartas Portuguesas. Gazeta de Notícias, Rio de Janeiro, n. 82, 25 mar. 1878. Disponível em: <http://memoria.bn.br/DocReader/docreader.aspx?bib= 103730_01\&pasta=ano\%20187\&pesq=>. Acesso em: 16 jun. 2015.

PASSOS, José Luiz. Machado de Assis - o romance com pessoas. São Paulo: Nankim; Edusp, 2007.

PERRONE-MOISÉS. Leyla. Stendhal e a era da suspeita. In: —. Flores da escrivaninha. 2. imp. São Paulo: Companhia das Letras, 2006. p. 21-28.

QUEIRÓs, Eça de. Correspondência. In: Obras completas de Eça de Queirós. Porto: Lello e Irmão, 1966a. v. 3, p. 487-672.

. O primo Basílio. In: Obras Completas de Eça de Queirós. Porto: Lello e Irmão, 1966b. v. 1, p. 865-1173.

REIS, Carlos. O essencial sobre Eça de Queirós. Lisboa: Imprensa Nacional-Casa da Moeda, 2005.

ROSA, Alfredo Machado da. Eça, discípulo de Machado? Rio de Janeiro: Fundo de Cultura, 19[??].

SANTIAGO, Silviano. Eça, autor de Madame Bovary. In: Uma literatura nos trópicos: ensaios sobre dependência cultural. São Paulo: Perspectiva, 1978. p. 49-65. SENNA, Marta de. "But then, what would criticism be?" Balzac reads Stendhal, Machado reads Eça. Revista de Estudos literários, v. 6, p. 135-155, dez. 2017. Disponível em: <http://impactum-journals.uc.pt/rel/article/view/4885>. Acesso em: 13 maio 2018. STENDHAL. A cartuxa de Parma. Trad. Vidal de Oliveira. Porto Alegre: Globo, 1943.

. Lettre à Balzac, 30 octobre 1840. Disponível em: <http://www.maremurex.net/ stendhal2.html>. Acesso em: 22 maio 2016.

Euvres posthumes. Correspondance inédite précedée d'une introduction par Prosper Mérimée. Paris: Michel Lévy, 1855.

THÉRANTY, Marie-Ève. Introdução. Balzac journaliste - articles et chroniques. Paris: Flammarion, 2014.

MARTA DE SENNA é pesquisadora do CNPq. Foi professora de Literatura Comparada na UFRJ e pesquisadora da Fundação Casa de Rui Barbosa, que atualmente preside. Sobre Machado de Assis, publicou dois livros: O olhar oblíquo do Bruxo e Alusão e zombaria; e 
organizou três: Machado de Assis: cinco contos comentados, Machado de Assis e o outro: diálogos possiveis e Machado de Assis: permanências (os dois últimos com Hélio de Seixas Guimarães). Idealizou e coordena o site www.machadodeassis.net. E-mail: martadesenna@gmail.com

Recebido: 16.06.2018

Aprovado: 24.06.2018 